\title{
An Evaluation of Writing Skills of EFL Learners in Kurdistan Region of Iraq
}

\section{Dara Karim Mahmood}

English Department, College of Languages, University of Human Development, Slemani, Kurdistan Region, Iraq

\section{Email address:}

dara.mahmood@uhd.edu.iq

\section{To cite this article:}

Dara Karim Mahmood. An Evaluation of Writing Skills of EFL Learners in Kurdistan Region of Iraq. International Journal of Language and Linguistics. Vol. 4, No. 1, 2016, pp. 14-24. doi: 10.11648/j.ij11.20160401.13

\begin{abstract}
This study attempts to evaluate English as a foreign language (EFL) learners' writing skills using error analysis (EA, hereafter) as a tool for the investigation. EFL is an understudied field in Kurdistan, especially in terms of writing skills and writing errors. The aim of the research is to identify, describe, analyze, and evaluate writing errors, their causes and sources, as well as discussing the role of EFL materials and their relation to EFL writing errors. Therefore, permission was gained to use a Cambridge standard writing test to examine the writing skills of EFL learners from two universities in Kurdistan using informal piloting. Furthermore, the study shows that these particular Kurdish EFL learners have serious problems in writing generally, and have weaknesses leading to errors in grammar, spelling, vocabulary, and punctuation - and particularly grammar. Hence, this paper can be a practical ground for EFL teachers, scholars, researchers, and students to understand Kurdish adult learners' writing errors and problems.
\end{abstract}

Keywords: EFL Kurdish Adult Learners, Second Language Writing, EFL Learners' Writing Errors

\section{Introduction}

Learning any foreign language, including English, is a continuous process that requires EFL learners to constantly make an effort and remain interested in order to learn and use the language well (Mitchell et al., 2013; Bandpay, 2012). Moreover, Halliday (2003) suggests that studying writing skills could be crucial for EFL learners as it allows them to better memorize English knowledge and use it when it is necessary. However, writing is a productive skill which is a very challenging, demanding and complicated task, not only for EFL learners but also for own language speakers of English. Therefore, it is widely believed that EFL learners are highly likely to make errors when it comes to writing (Tsai and Lin, 2012).

Furthermore, Myles (2002) argues that L2 writing is conscious and is learned consciously so learning the language and writing it appears to be separate to some extent. This requires students to learn the language and write at the same time. Additionally, Ferris (2009) argues that this separation might be the reason behind finding learning L2 writing difficult and complicated. Concerning English as a foreign language (EFL), Smith (2005) believes that it is the English language's irregularity, complexity, and ambiguity that make it hard to learn, especially the writing element, and this is why learners consequently make errors.

Certainly, this life-time process of English language learning will have errors that EFL learners make and which are seen as a significant part of English language learning (Keshavarz, 2004). According to Corder (1976, cited in Lightbown and Spada, 2013), errors of L2 learning are not only important for the learners to learn from, but also for teachers, linguists, and researchers to investigate learners' progress and provide them with better instructions and knowledge for the future.

Concerning the types of errors, some argue that they mostly occur in grammar, while others believe that vocabulary errors are most common. Furthermore, views of the causes of errors in EFL learners' written performance have been evolved and varied. At first, it was claimed that L1 interference is the only reason behind L2 learners' errors (Lightbown and Spada, 2013); however, some linguists argue that L1 interference has a considerable influence on L2 learning but it is not considered the only source. In addition, some recent studies have introduced new terms that hold similar notions of L1 interference such as "L1 transfer or cross-linguistic influence" (Ortega, 2009, p. 31). In addition to that, other linguists, led by Chomsky in 1957, argue that 
L1 interference or transfer cannot always explain L2 learners' errors and there are other developmental factors that lead EFL learners to commit errors in their writing (Ellis, 2008; Cook and Newson, 2007).

In the field of EFL, there has been great attention paid to writing skills in the past few decades. Therefore, it is widely studied throughout the world, and studies of writing skills have increased due to their significance and necessity in education, especially for international students who study in countries where English is the L1 (Deqi, 2005). Thus, this paper attempts to shed light on the quality and significance of EFL undergraduate learners' writing skills in Kurdistan who are very likely to study abroad for their postgraduate degrees, especially in English speaking countries and become ESL learners in the future.

\section{Literature Review}

This section attempts to familiarize the reader with an overview of the EFL field and its relation with L2 writing are discussed, as well as, EFL error types that occur in writing.

According to Nunan (2001, p. 306), EFL is "the teaching and learning of English in communities where it is not widely used for communication". For this very purpose, this research has gathered data from some Kurdish EFL learners in Kurdistan where English language is not used for communication; instead, the Kurdish language is used for that purpose.

One should be aware of errors and their types in studies. An error is, therefore, a commonly-used term in language learning, yet it is difficult to define and address precisely. However, Ellis (1997, p. 18) claims that errors are "systematic" and "predictable", therefore, they seem to be a suitable tool to deal with the EFL learners' written competence and performance.

Furthermore, there are several definitions to errors. McDonogh (2002) defines errors distinguishing two situations. In the first situation, the learners have the ability and knowledge to use the target language (TL, hereafter) rules accurately, but $\mathrm{s} /$ he sometimes fails to apply them. In the second situation, learners may not have accurate knowledge of the TL rules or are not aware of the rules at all. McDonogh (2002) considers the outcome of the first situation a mistake or slip of the tongue and the second situation an error.

Similarly, Brown (2000, p. 257) states that an error "reflects the competence of the learner", whereas a mistake is made when there is "a failure to utilize a known system correctly". Hence, one can judge a particular learner's ability in the TL by knowing whether the learner makes mistakes or errors. Moreover, Brown (2000) also points out that one may not be able to "tell the difference between an error and a mistake" in every situation; however, learners "do make errors, which can be observed, analyzed and classified to reveal something of the system operating within the learners" (pp. 217-218).

Moreover, Weir's findings (1988, p. 18) are still considered one of the excellent studies that confirm EFL learners' errors specifically in writing skills (Al-Buainian, 2009), which can be summed up as:

1) Grammatical errors

2) Vocabulary or lexical errors

3) Spelling errors

4) Punctuation errors

Weir and others argue that those errors are the most common ones in EFL writings and believe that EFL learners make more errors in grammar and vocabulary (Al-Buainian, 2009). As a result, this study assesses its samples based on the mentioned error types.

\section{Methodology}

This chapter is divided into research approach, ethics, sampling, experiment, and the data analysis methods and procedures.

In the literature, qualitative research is a type of research approach which does not necessarily employ numerical data collection and the data are not analyzed, interpreted and reduced easily to numbers (Kumar, 2011). According to Lowhorn (2007), some make assumptions that the results of a qualitative research can be projectable but this is not totally correct. This investigation deals with a small sample size of 30 EFL learners, which can establish a feasible and firm basis for making decisions on the issue and similar issues that arise, as well as, similar studies that are done in the future.

Furthermore, a qualitative approach is not only suitable for investigating social sciences (Barbour, 2008), but also allows researchers to interpret meanings rather than measuring the social behavior and understandings of the social world (Summer, 2006). It is therefore crucial to have an overview of what is meant by qualitative approach. Payne and Payne (2004, p. 175) give a clear definition that "qualitative methods produce detailed and non-quantitative accounts of small groups, seeking to interpret the meanings people make of their lives in natural settings". This will, hopefully, provide a clear ground to understand EFL learners' writing errors in Kurdistan.

Significantly, a qualitative approach is often associated with subjectivity, interpretivism and experiments (Silverman, 2013; Summer, 2006). According to Anderson (2009, p. 135), interpretivists aim to comprehend individuals' experiences or a group of people and their social realities in order to give a meaning to the collected data, which can also be analyzed and compared with other works that were advanced by others (Denscombe, 2010). Thus, it has been employed to answer research questions that could have been difficult to answer using another research approach with its current form and aims. However, some features of a quantitative approach can be seen throughout the study because both approaches share some features and are not totally different. Creswell and Clark (2007) argue that "no one study is purely quantitative or qualitative and that each method has many of the same elements" (Cited in Soiferman. 2010, p. 7).

In addition to that, approval was gained from the places of 
research which were two universities in Kurdistan. Consent was later obtained from the participants. They were all provided with the detail of the research before taking the test. Also, they were informed that they had the right to withdraw their data if they felt uncomfortable at any time during the research.

What is more, a standardized test of the University of Cambridge was used as the source of the test, which is Cambridge ESOL Level 1 Certificate in ESOL Skills for Life [Writing]/Sample Paper, and the test authority was contacted via email and post in the UK. Therefore, the copyright and permission were gained from Research and Validation Office, Cambridge English Language Assessment, which is part of the University of Cambridge, to enable the research to use the test for this study.

Regarding the samples, in collecting a qualitative data such as the one in this study, Dornyei (2007) and O'Leary (2010) believe that increasing the number of samples to around thirty would be ideal and anything more than thirty might be difficult to researchers. In addition, qualitative research usually deals with small sample sizes. Similarly, Punch (2009, p. 99) argues that "the minimum number seems to be between twenty and thirty... what is important is that to justify rigorously any sample size". Hence, 30 students were taken as samples for the writing test, and 26 of them have provided useful answers to be used as the source of data.

This study has selected its samples based on their interest and desire to voluntarily participate in the study; however, they had to be third year undergraduate students at the English department in their universities that enables them to be capable of taking the test.

\subsection{Experiment}

There are many ways to conduct a research, and for this particular one, the strategy of experiment is chosen. An experiment can be defined as "a situation in which the independent variable is carefully manipulated by the investigator under known, tightly defined and controlled conditions, or by natural occurrence" (Blaxter et al., 2010, p. 75).

Furthermore, one of the important features of an experiment that is followed by the researcher is having random samples in a particular population in order to provide an equal opportunity for them to participate in and obtain genuine, useful and real-life information or data from the informants (Mackey and Gass, 2005). Moreover, Cook (2002) believe that experiments and other strategies of research have weaknesses; however, McGowan $(2011$, p. 1) argues that "a well-designed experiment is the best method for establishing efficacy of any intervention" in different fields of research, 'education', for example. What is more, Gomm et al. (2002) further argue that experimental studies are one of the most effective ways to obtain result replicability and give research a great deal of generalizability. Therefore, an experiment of some EFL learners in Kurdistan randomly from two universities and collecting data from their answers as it was the most suitable strategy.

\subsection{Data Analysis}

The data were organized and categorized in thematic approaches that emerged from the categorization based on the types of errors the learners made in terms of grammar, vocabulary, spelling and punctuation. Therefore, error analysis (EA) is used to categorize the errors of the EFL learners and they are going to be discussed in the next chapter.

Furthermore, Corder's error analysis steps which he established in the 1970s are still considered the clearest route to deal with errors in EFL (Lightbown and Spada, 2013). The first step is to collect data from some samples, which have been dealt with previously. Error analysis (EA) can be defined as a "technique for identifying, classifying and systematically interpreting the unacceptable forms produced by someone learning a foreign language, using any of the principles and procedures provided by linguistics" (Crystal, 2008, p. 165).

In addition, Corder (1974, cited in Lightbown and Spada, 2013) puts the second step as describing the errors. Later, he (1974) argues that analyzing the errors will be beneficial in various ways. Some believe that the study of those errors by teachers will help them to be more familiar with diagnosing errors and learning how to deal with them. It will also create better materials for the learners (Ellis, 2008). Others think that errors can be used to gain knowledge about EFL learners' progress and how to improve it (Al-Saudi, 2013).

\section{Analysis}

In this chapter, the gathered data from the writing test are identified, described, explained, and evaluated based on the literature and the research questions.

\subsection{Writing Errors of the EFL Learners in Kurdistan}

The EA identification step is implemented first in order to provide answers for the research questions, and errors are firstly recognized, and then categorized, and described into different types in this section.

Interestingly, only half of the 26 learners have written the required number of words. For this reason, the errors were taken from the first 100 words of each answer sheet to discover the frequency of errors and this meant 2600 words in total. The pie chart illustrates the percentage of the errors identified in all of the learners' answer sheets (Figure 1).

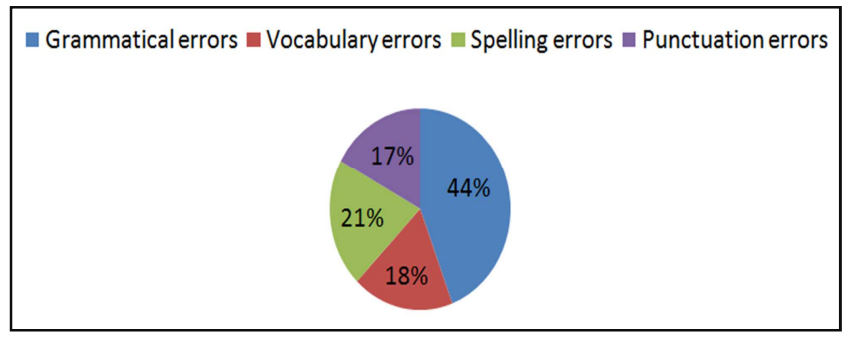

Figure 1. EFL learners' writing errors in Kurdistan. 
As mentioned in the literature review, grammar errors are generally expected to appear in EFL learner texts and, interestingly these are the most ones that appeared most frequently in the EFL learners' writing texts in this study. This contradicts some researchers' works who argue that EFL learners' vocabulary errors outweigh grammatical errors as the EFL learners seem to have serious difficulty with grammar and have made more grammatical errors than any other kind (Appendix 1). Besides, the table in appendix 1 shows that learner number 1 is the only one who made an equal number of grammatical and spelling errors while all the other 25 learners made more grammar errors than spelling, vocabulary, and punctuation errors.

Furthermore, errors in vocabulary, spelling, and punctuation show very similar percentages which are $18 \%, 20 \%$ and $17 \%$ respectively, and are not as common as grammatical ones. Moreover, the pie chart illustrates that approximately half of the errors are grammar-based that could be due to various reasons which will be explained later in this chapter. Thus, according to the results of this study, there are still a great number of Kurdish EFL learners who commit many grammatical errors, and more than any other kind of error in their writing despite receiving a great deal of English language grammar teaching in their lectures and classes (Salusbury, 2004). Therefore, it would be more useful for the EFL teachers in Kurdistan to reconsider their ways and provide more comprehensible and effective ways of studying and dealing with (teaching) grammar in order to reduce the errors, especially grammatical ones, and enable the EFL learners to produce a better writing with fewer or no errors.

\subsubsection{The EFL Learners' Common Grammatical Errors}

The EFL learners had mostly committed grammatical errors and most of them are evident in basics of grammar, such as; errors in using third person singular ' $s$ ' that appeared in most of the learners' answer sheets (See appendix 2 for examples). In the first three examples of the list in appendix 4 , the learners fail to use third person singular ' $s$ ' which is necessary and affects the meaning. The examples of 2, 3 and 4 , however, show that some of the learners have used the ' $s$ ' with the past form of the verb which is wrong.

Moreover, the learners have made errors in using pronouns accurately. In example number 5, it is assumed that the learner is trying to focus on that $\mathrm{s} / \mathrm{he}$ loves the celebration, while s/he fails to use pronoun 'I' which is necessary. In example number 6 (appendix 2) 'hisself' is used instead 'himself' which is grammatically incorrect.

Furthermore, examples 7-12 show some of the EFL learners' common errors in using the plural 's'. The words (benefit, activity, celebration, and event) have to be pluralized by adding plural 's' as they are preceded by a marker or a quantifier that requires a plural noun, not a singular one. However, in examples 11 and 12, the plural 's' was added to 'children' while it is the plural form of 'child' and does not require plural 's', and also the 's' was added to 'year' while it is preceded by 'every' that is used with a singular noun.
Moreover, none of the learners used the correct preposition with dates. Most of them have used 'in' and others used 'at' instead of 'on' which is grammatically unacceptable, that can be seen in examples 13 and 14 (Appendix 2). What is more, errors in using the verb "to be" are presented in the examples from 15 to 19. In those examples, the main verbs that follow the auxiliary verb 'are' require 'ing' and should be (making, visiting, travelling, and expressing). In addition to that, the next two examples of 20 and 21 show the learners' inaccuracy in word order and were one of the most frequent errors appeared in their writings. Those examples are considered grammatically inaccurate while one can fully understand what the writer wants to convey.

Finally, the table's last four examples show how some of the learners failed to use the articles ' $a$ ' and 'an' accurately. Furthermore, the grammatical rules are 'a + vowel' and 'an + consonant'. Also 'a' and 'an' are followed by a singular noun, while in the last three examples 'a' is used with a plural noun, which is grammatically wrong.

\subsubsection{The EFL Learners' Common Vocabulary Errors}

There are different types of vocabulary errors. In this study, the vocabulary errors that appeared in the Kurdish learners' answer sheets can be divided into two general types. First, errors caused by missing a word, a particle of a phrase or a sentence that affected the meaning of it and is considered wrong. These can be seen in the first three examples of the list of vocabulary errors (Appendix 3). Secondly, the rest of the examples in the vocabulary error list indicate that the EFL learners have difficulties choosing the correct word that can collocate with the context of the sentence and convey a proper sense or meaning to a reader. This, to a great extent, contradicts what Mahan (2013) and Simensen (1998) stated because the Kurdish EFL learners make many errors when it comes to language internalization and using proper words in their proper contexts, while they have made fewer errors due to their lack of vocabulary.

\subsubsection{The EFL Learners' Common Spelling Errors}

According to the table of appendix 3, only three of the EFL learners made no spelling errors, while the other 23 learners have made different types of errors, which can be seen as one of the most serious difficulties that the learners have after grammar. Crystal (2013, p. 223) describes four basic types of spelling errors as: "omissions, additions, substitutions, and inversions" and claims that "other possibilities are rare". Therefore, this study deals with the spelling errors according to Crystal's classification, and examples of each type are shown in appendix 4.

On one hand, Crystal (2013) believes that other types of spelling errors are 'rare' (p. 223); on the other, Peck and Coyle (2005) argue that EFL learners are expected to make other spelling errors, such as; splitting one word into two, or joining two words and regarding them as one, and these are two other common spelling errors in the Kurdish EFL learners' writings. Table 1 contains examples of inaccurate word separation and word annexation that are frequently repeated in the Kurdish learners' writings. 
Table 1. Inaccurate word separations and annexations.

\begin{tabular}{llll}
\hline Typical error/Word separation & Correct form & Typical error/Word annexation & Correct form \\
\hline there fore & therefore & alot of & a lot of \\
out side & outside & eachother & \\
to gether & together & & \\
how ever & however & & \\
now adays & nowadays & & \\
\hline
\end{tabular}

\subsubsection{The EFL Learners' Common Punctuation Errors}

Punctuation error identification is based on the works of Shokouhi and Dabbagh (2009), Field (2009) and Peck and Coyle (2005), and the list below represents the typical punctuation errors the Kurdish EFL learners made. Additionally, appendix 5 contains some of the most frequent punctuation error examples that appeared in the Kurdish learners' answers, which basically are:

- Starting sentences with the word 'and';

- Starting sentences with small letters;

- First letter of the names of the months in small letters;

- Using a small 'i' when writing the pronoun 'I';

- Improper use of commas, and sometimes forgetting to use one when it is required;

- Improper use of capital letters;

- Improper use of semicolons;

- Long paragraphs with no punctuation;

- Long single-sentence paragraphs;

- Overusing the conjunction of 'and'.

\subsection{Error Explanation}

To begin, the most frequent errors which are dealt with in the literature are broadly classified into grammatical, spelling, and punctuation errors as well as lexical or vocabulary errors. Interestingly, in this study, the findings show that the learners' most frequent error lies initially in grammar, then spelling, vocabulary, and punctuation which have been separately discussed in the literature review.

In this section, the explanation and evaluation step of EA takes place to find out the possible reasons behind them based on the collected data and by comparing them to the literature. The literature suggests that there are two sources causing EFL learners' grammatical and vocabulary errors and these are L1 influence and developmental factors (Ellis, 2008).

\subsubsection{L1 Influence}

The word 'influence' is used as the L1 can work either positively or negatively, particularly on grammar and vocabulary. On one hand, the influence can be positive and facilitate the learning of an L2, like English. On the other hand, it can hinder learning English and lead errors being made (Kavaliauskiene, 2009).

Some of the EFL learners' errors are committed by misusing grammatical rules of singular and plural markers, and they seem not to be able to differentiate between them properly. This can be explained by the factor of L1 influence.

E. g. $(*)$ many benefit
(*) many activity

(*) there are other celebration

(*) myself love this celebration

(*) People is happy.

(*) People go to street Salim.

(*) in the 21 st of March

Take 'many benefit' as an example. In Kurdish, it could be said "zor swd"which translates exactly as thany benefit". Here, $s w d "$ has a plural connotation in Kurdish that requires no addition to make it plural. Moreover, the grammatical rule in Kurdish is 'zor $+s w d$ ' that is 'many + benefit' which should be 'many + benefits' in English, and this type of error occurs with most of the EFL learners' answer sheets.

In addition, EFL learners seem to have difficulty with vocabulary, and sometimes choose words inaccurately. This is widely explained to be the result of L1 influence (Ridha, 2012). For example, one of the most repeated errors in the answer sheets was 'in the 21st of March' and no learner has used the correct preposition 'on' when writing dates.

In Kurdish, ' $i n^{\prime}$ means ' $l a$ ' literally and that seems easier for the learners to use with dates, while they should use 'on' which mostly means 'lasar'. This sounds odd in Kurdish to be used with dates. What is more, learners appear to be making a sensible choice according to Kurdish language rules while the choice is wrong when it comes to English. Thus, it is highly likely that the Kurdish influence will negatively affect EFL learners' grammar and vocabulary competence, especially the Kurdish adult learners in the study as Ellis (2008, p. 55) claims that "transfer errors are more common in adult learners".

Thus, we can see that L1 influence can affect EFL learners in Kurdistan; they sometimes seem to depend on their L1 while producing an English phrase and depend on literal translation from Kurdish into English. What is more, Abdulrahman (2012, p. 121) suggests that Kurdish EFL learners commit most of their errors in writing due to L1 influence, and argues that the EFL learners in Kurdistan "frequently write/express ideas in English which sound Kurdish". However, some researchers argue that there are some developmental factors that could explain EFL learners' errors in writing (Keshavarz, 2004).

\subsubsection{Developmental Factors}

As mentioned before, L2 learning is a continuous process and learners generally go through a developmental process in which they use the L2 based on a cognitive process (Keshavarz, 2004). Therefore, in this developmental and continuous process, EFL learners are likely to make errors 
that are mostly arbitrary and that cannot be explained only by L1 influence. This means there must be other sources and reasons behind them. Ellis (2008) and Brown (2000) consider other error sources that appear in EFL learners' written works and simply divide them into: omission or simplification, and ignorance of rule restriction or overgeneralization.

Firstly, omission errors occur when learners simplify or leave out one or more element. Here are some examples in table 2 .

Table 2. Examples of omission errors.

\begin{tabular}{ll}
\hline * everyone say & $*$ nearly month later \\
* the day which account for & * some people participate festival \\
$*$ the visitors are visit & * some talent people perform \\
* the people are travel & $*$ the major in women believes in it. \\
* you can anything you want. & * Qaradagh is part of my country I \\
\hline
\end{tabular}

The EFL learners have left out some important parts of some words, such as; third person singular's', 'ing', articles 'a/an', part of phrasal verbs like 'participate' instead of 'participate in' and 'grew up' instead of 'grew up in'. Furthermore, verbs and nouns are omitted which affects meaning and produces an incorrect sentence.

Secondly, some errors occur when learners create a specific structure based mainly on the TL, and use that structure in irrelevant or wrong contexts. Thus, they overgeneralize some rules (Lightbown and Spada, 2013). In other words, the learners add or overuse at least one element with a word, phrase or sentence that is not necessary and which could show their ignorance of the rules of English (Abdulrahman, 2012). Table 3 contains examples from the learners' writing test in which they have added a third person singular's' to the past form of a verb, overused auxiliary verbs of 'is and are' and added a plural 's' to singular words or phrases.

Table 3. Overgeneralization examples.

\begin{tabular}{ll}
\hline$*$ a big celebration tooks place & $*$ childrens \\
$*$ which is takes place & $*$ a new clothes \\
$*$ they take a pictures & $*$ a delicious foods \\
$*$ they are express happiness & \\
\hline
\end{tabular}

To sum up, the errors that occur due to simplification or omission and overgeneralization could have been made due to the result of lack of knowledge, including ignorance of vocabulary, amongst inexperienced Kurdish EFL learners. This confirms Erdogan's (2005, p. 266) argument that vocabulary developmental errors can occur as a result of "the learners' attempt to build up concepts and hypotheses about the target language from their limited experience with it".

\subsection{Sources of Spelling and Punctuation Errors}

Although spelling is an important part of learning an L2, little study has been made in the Kurdistan context especially when compared with studies carried out in Asian contexts like Japan, Thailand, and Arab countries. This can be considered as another crucial reason for this study. Furthermore, some researchers claim that L1 and L2 differences in EFL learners tend to cause EFL learners' spelling errors; however, others argue that spelling errors occur because of other reasons including the EFL learners' pronunciation and the lack of English spelling knowledge (Naruemon, 2012). Interestingly, the EFL learners appear to make spelling errors mainly because of pronunciation and lack of the spelling knowledge. Here are some examples in table 4.

Table 4. Spelling errors due to pronunciation and lack of spelling knowledge.

\begin{tabular}{ll}
\hline Errors due to pronunciation & $\begin{array}{l}\text { Errors due to lack of spelling } \\
\text { knowledge }\end{array}$ \\
\hline$*$ diffrent /difront/ & $*$ etting \\
$*$ wich /witf/ & $*$ eachother \\
$*$ mosc /mbsk/ & $*$ remmemberance \\
$*$ neibour /nerbə(r)/ & $*$ nagabour \\
$*$ intresting /nt(o)ristry/ & $*$ to gether \\
$*$ creat $/ \mathrm{kri}$ eit/ & $*$ alot of \\
$*$ meny /meni/ & $*$ citys \\
\hline
\end{tabular}

However, there are still some spelling errors that can be explained by L1 influence. For example, using *vistival for $<$ festival $>$, *poletic for $<$ politic $>$, and $*$ rejim for $<$ regime $>$. Here it appears that the learners have followed the Kurdish pronunciation directly and consequently made spelling errors as these words are used in Kurdish and pronounced like /festival/, /poletik/ and /redzim/.

Finally, punctuation errors are widely believed to occur when learners do not have enough knowledge and information about punctuation marks (Cook, 2008). The marks have their own rules that should be taught and learned whether inside or outside English classes or sometimes through reading. In this study, the learners have made fewer punctuation errors than grammatical, vocabulary, and spelling ones that could be due to learning punctuation rules in classes and from their materials. Elkilic et al. (2009), Cook (2008), and Peck and Coyle (2005) argue that in spite of L1 interference even in punctuation errors, the most apparent reason behind these kinds of errors is ignorance of the rules either from teachers/learners or materials, and this could be true for EFL Kurdish learners. For example, some have left out full stops (periods) before starting a new sentence, and others have not used capital letters where they are required to. However, the learners have made punctuation errors less than the other types of errors that can be regarded as a positive sign in their writings.

\subsection{Possible Remedy for Errors in Writing in General}

Initially, the literature suggests two different areas that need to be considered to reduce writing errors. These are teaching methodology and providing corrections or feedback. In the first treatment, the teaching methodology should be reconsidered if many errors occur in EFL learners' writings. Some are rather skeptical about the best language teaching method in general. Mitchell et al. (2013) and Nunan (2001) believe that there is not a perfect teaching method for all situations, and it is the teachers' responsibility to choose the 
most effective method in their context. Furthermore, AlBuainain (2009) makes a point that teaching writing is as controversial and problematic as teaching other skills because there are various ways to teach EFL classes; however, they should attempt to discover what teaching method can best improve the EFL learners' writing skills, including Kurdish EFL learners.

In Kurdistan, the universities' writing course objectives and classes revolve mostly around teaching the process of writing for EFL students rather than other feasible and suitable skills that their learners need. This will consequently affect their writing and prevent them from making major improvements (Hinkel, 2011). In addition, Erdogan (2005, p.270) states that errors "provide feedback about the effectiveness of teaching techniques and show the teacher what part of the syllabus being followed needs further attention". Thus, it would be more useful for their EFL courses to concentrate on the content of the language and accuracy rather than the process of it as learners seem to need more information about this. So, this could be seen as a useful and suitable teaching style for those learners.

Secondly, the literature widely suggests that one of the most useful ways to deal with errors is to provide solutions by correcting them (Hashimoto, 2004). Ellis (1994, cited in Hashimoto, 2004, p. 12) uses terms like 'feedback', 'repair', and 'correction' to refer to error correction generally and its contribution to reducing EFL learners' errors in writing.

The Kurdish EFL learners appear to commit many errors, especially in grammar; thus, teachers should account for their errors by providing more corrections and enough feedback in order to reduce them (Sadeghpour, 2013). Lee (1997) classifies types of error treatments into direct correction, in which the teacher should tell his/her students that the form they used is incorrect and provide them with the correct structure, and indirect correction in which the teacher guides his/her students to revise and make possible corrections without telling them what these are. This relies on the students discovering them for themselves.

Moreover, Beuningen (2010), and Erel and Bulut (2007) investigated the impact of direct and indirect correction or feedback and found out that both are effective in helping EFL learners to improve their writing accuracy. However, their studies show that indirect correction or feedback is far more effective and crucial than direct correction, as the latter provides the learners with short-term accuracy improvement while indirect correction has a long-term effect on learners' writings. Therefore, the teachers in Kurdistan should follow the long-term strategy in correcting errors in order to help their students reduce their errors permanently. However, it is believed that correcting all errors is not necessary and errors should be selected based on their frequency in texts (Hashimoto, 2004). This is because correcting every single error can be time-consuming, and put teachers and EFL learners under too much pressure (Ellis et al., 2008), and could cause an overload for the learners (Bitchener and Knoch, 2009). For this purpose, teachers and researchers can get benefit from categorizing errors as has been done in this chapter. This would go through the common types of errors and provide the learners with enough corrections instead of correcting every error. Moreover, teachers need to be very careful while correcting errors and remember to reward their students in order to keep them motivated (Iseni, 2011).

\section{Conclusions and Recommendations}

In this chapter, a synopsis is given about the research findings with reference to the literature and aims of the research which are to examine Kurdish EFL learners' common writing errors, possible reasons behind their errors, the role of materials for them and a possible remedy for writing errors in general. It also gives recommendations and identifies professional and personal developments. Finally, the researcher concludes the study with dissemination ideas or suggestions for further research about evaluating EFL learners' writing skill.

Besides, this study has shown that the EFL learners' most common errors are in grammar, spelling, vocabulary and punctuation respectively. In addition, the test reveals that the learners have also committed two more common error types in almost the same proportions - vocabulary (18\%) and punctuation (17\%). This reinforces Weir's findings (1988) which are discussed in the literature review because it is still considered one of the most useful studies that can examine specific errors in writing. On the other hand, it does contradict other studies in certain respects.

Moreover, possible reasons behind EFL learners, writing errors of those were discussed based on the existing literature. Grammatical and vocabulary errors were discussed first due to sharing similar causes. L1 influence is one of the major reasons behind the EFL learners' grammatical and vocabulary errors and this confirmed evidence presented in the literature review and based on recent and relevant studies by (Abdulrahman, 2012; Ridha, 2012; Ellis, 2008). Ridha (2012) and Ellis (2008) argue that L1 can explain most L2 writing errors; furthermore, Abdulrahman (2012) believes that Kurdish EFL learners' main source of writing errors is still L1 interference. This confirms one of the findings of this study that L1 has a great influence on the learners' grammar and vocabulary competence.

What is more, the study has revealed that some of the learners' grammatical and vocabulary errors are evident due to developmental factors. This confirms Keshavarz's (2004) and Brown's (2000) investigations of EFL learners' writing errors. Brown (2000) breaks developmental factors down further into omission or simplification and overgeneralization. These were noticed in the Kurdish EFL learners' errors and discussed in detail in the analysis chapter.

Furthermore, Subhi and Yasin (2015) and Naruemon (2012) claim that spelling errors are made due to the impact of pronunciation and lack of spelling knowledge; however, the study has discovered that there are some spelling errors which can only be explained by L1 influence. Moreover, the literature suggests that the only reason for punctuation errors is the ignorance and lack of awareness of punctuation mark 
rules on the part of teachers/learners or their materials. So, punctuation errors are made if EFL learners do not have enough knowledge about punctuation marks' rules and usage (Cook, 2008; Peck and Coyle, 2005).

Finally, concerning the remedy for errors in their writings, the literature suggests that the most acceptable way to deal with errors is to provide feedback from teachers by correcting the errors either directly or indirectly. In other words, this needs direct or indirect correction or feedback (Tootkaboni and Khatib 2014; Beuningen, 2010; Hashimoto, 2004; Ellis, 1994).

Recommendations arising from the study.

According to the literature, evaluating EFL learners' writing skills and discovering their writing errors appear to be an important part of research as they have been

investigated more in the last few decades. Thus, there are still many new ideas and information gaps to be studied, especially in the Kurdistan context.

Furthermore, this research provides a useful basis for further studies of Kurdish EFL learners' errors. Besides, universities and educational orgnizations in Kurdistan can expand the number in the sample as well as implementing other possible types of research methods such as interviews, surveys, and questionnaires. This will give a more precise understanding of the learners' progress and provide them with better opportunities to learn English, and this can also give an overview to teachers who work on students' writing skills.

\section{Appendix I}

Table A1. The Kurdish EFL learners' errors individually.

\begin{tabular}{|c|c|c|c|c|}
\hline Learner Number & Grammatical errors & Vocabulary errors & Spelling errors & Punctuation errors \\
\hline Learner 1 & 7 & 5 & 7 & 6 \\
\hline Learner 2 & 9 & 3 & 6 & 4 \\
\hline Learner 3 & 14 & 7 & 4 & 5 \\
\hline Learner 4 & 11 & 4 & 4 & 2 \\
\hline Learner 5 & 12 & 3 & 6 & 6 \\
\hline Learner 6 & 9 & 4 & 5 & 3 \\
\hline Learner 7 & 12 & 5 & 6 & 7 \\
\hline Learner 9 & 9 & 4 & 4 & 3 \\
\hline Learner 10 & 4 & 2 & 0 & 0 \\
\hline Learner 11 & 11 & 4 & 7 & 2 \\
\hline Learner 12 & 7 & 2 & 0 & 3 \\
\hline Learner 13 & 12 & 6 & 8 & 5 \\
\hline Learner 14 & 8 & 2 & 5 & 3 \\
\hline Learner 15 & 12 & 5 & 5 & 4 \\
\hline Learner 18 & 8 & 4 & 7 & 6 \\
\hline Learner 19 & 6 & 1 & 3 & 5 \\
\hline Learner 20 & 9 & 4 & 4 & 3 \\
\hline Learner 21 & 9 & 5 & 6 & 3 \\
\hline Learner 22 & 11 & 4 & 7 & 2 \\
\hline Learner 23 & 7 & 2 & 0 & 0 \\
\hline Learner 24 & 8 & 7 & 3 & 6 \\
\hline Learner 25 & 7 & 4 & 0 & 2 \\
\hline Learner 26 & 8 & 2 & 2 & 3 \\
\hline Total of errors & 249 & 102 & 116 & 96 \\
\hline
\end{tabular}

\section{Appendix II}

Table A2. The EFL learners' common grammatical errors.

\begin{tabular}{ll}
\hline Errors & Correct forms \\
\hline 1. Everyone say & Everyone says \\
2. The day which account for & The day which accounts for \\
3. It's a wonderful place that make me happy. & It's a wonderful place that makes me happy. \\
4. A big celebration tooks place in the city. & A big celebration took place in the city. \\
5. Myself love this celebration. & I (myself) love this celebration. \\
6. Hisself & himself \\
7. It brings many benefit. & It brings many benefits. \\
8. Many activity & Many activities \\
9. There are other celebration. & There are other celebrations. \\
10. One of the most famous event & One of the most famous events \\
11. Childrens & Children \\
12. Every years & Every year \\
13. In the 21st of March & On the 21st of March \\
\hline
\end{tabular}




\begin{tabular}{ll}
\hline Errors & Correct forms \\
\hline 14. At the 21st of march & On the 21st of March \\
15. Families are make foods. & Families are making foods. / Families make foods. \\
16. The visitors are visit & The visitors are visiting \\
17. The people are travel & The people are travelling \\
18. Kurdish people are enjoyed it. & Kurdish people are enjoying it. \\
19. They are express happiness. & They are expressing happiness. \\
20. We every year celebrate Newroz. & We celebrate Newroz every year. \\
21. People go to street Salim. & People go to Salim street. \\
22. a information & an information \\
23. a new clothes & new clothes / a new cloth \\
24. a delicious foods & a delicious food / delicious foods \\
25. they take a pictures & they take pictures / they take a picture \\
\hline
\end{tabular}

\section{Appendix III}

Table A3. Examples of the Kurdish EFL learners' vocabulary errors.

\begin{tabular}{ll}
\hline Errors & Correct form \\
\hline 1. You can anything you want. & You can do anything you want. \\
2. Qaradax is part of my country I grew up. & Qaradax is part of my country I grew up in. \\
3. Some people participate festival. & Some people participate in the festival. \\
4. At first I cannot believe my eyes. & At first I could not believe my eyes. \\
5. There are many participations in my hometown. & There are many events in my hometown. \\
6. Newroz is a nationalist celebration. & Newroz is a national celebration. \\
7. It is the symbol of breaking all unfair and unjustic. & It is the symbol of freedom and liberty. \\
8. They help the people to be a good day. & They help the people to have a good day. \\
9. People recite the song. & People sing the song. \\
10. It is very crowd. & It is very crowded. \\
11. People go to tourism places. & People go to tourist places. / People go to resorts. \\
12. It caused that glitter victory. & It caused that amazing victory. \\
13. Most people stay for few days. & Most people stay for a few days. \\
14. The economy is growing up and losing money. & The economy either grows or loses money. \\
15. That day we create a variety of food. & That day we make various foods. \\
16. If you look nearly at this celebration & If you look closely at this celebration \\
17. The major of women believe in it. & The majority of women believe in it. \\
\hline
\end{tabular}

\section{Appendix IV}

Table A4. Examples of the Kurdish EFL learners' spelling errors.

\begin{tabular}{llll}
\hline Omission errors & Correct from & Addition errors & Correct form \\
\hline Diffrent & Different & Eatting & Eating \\
Wich & Which & hometowen & Early \\
Mosc & Mosque & Earlly & wonderful \\
Befor & Before & wonderfull & remembrance \\
Som & Some & remmemberance & Empty \\
Intresting & Interesting & Empity & Around \\
Teritory & Territory & Arround & Hours \\
Chiken & Chicken & Houers & Picnic \\
Communcation & communication & pickneck & Correct form \\
Substitution errors & Correct form & Inversion errors & Friends \\
Etting & Eating & freinds & Foriegn \\
Beaueful & Beautiful & forigen & Fire \\
Aniual & Annual & Fier & \\
a little bet & a little bit & & \\
Poletic & Politic & & \\
Vistival & Festival & & \\
Delishes & delicious & & \\
enjoied / injoyed & Enjoyed & & \\
Intertain & Entertain & Many & \\
Meny & & & \\
\hline
\end{tabular}




\section{Appendix V}

Table A5. Examples of the Kurdish EFL learners' punctuation errors.

\begin{tabular}{ll}
\hline Typical errors & Correct form \\
\hline They cook traditional food. and they go to a park. & They cook traditional food, and they go to a park. \\
it is called newroz. in this day people enjoy their time. & It is called Newroz. In this day, people enjoy their time. \\
The 21st of march & The 21st of March \\
In celebrating people are happy. & In celebrating, people are happy. \\
Here i will talk about one of them. & Here I will talk about one of them. \\
This Celebration is Very imPortant. & This celebration is very important. \\
Such as Iran and Armenia and Azerbaijan. & Such as Iran, Armenia and Azerbaijan. \\
People are very happy at that Day, They wear Kurdish traditional clothes. & People are very happy at that day, and they wear Kurdish traditional clothes. \\
\hline
\end{tabular}

\section{References}

[1] Abdulrahman, B. S. (2012). Effects and implications of pragmatic competence for enhancing EFL university students' written performance. UK, Milton Keynes: Author House.

[2] Al-Buainian, H. (2009). Students' writing errors in ESL: A case study. Department of English and Modern European Languages, the Journal of Education Department, 19(1), 1-37.

[3] Al-Saudi, J. (2013). Error analysis and spelling mistakes of EFL learners at Tafila Technical University: A case study. Frontiers of Language and Teaching, 4, 99-107.

[4] Anderson, V. (2009). Research methods in human resource management. ( $2^{\text {nd }}$ ed.). London: Chartered Institute of Personnel and Development.

[5] Bandpay, A. B. (2012). A survey on the impact of L1 grammar negative transfer on L2 writing skill in Iranian EFL sudents in Rudsar city. The Iranian EFL Journal, 8(6), 204-226.

[6] Barbour, R. S. (2008). Introducing qualitative research: A student's guide to the craft of doing qualitative research. Thousand Oaks, California; London: SAGE Publications.

[7] Beuningen, C. V. (2010). Corrective feedback in L2 writing: Theoretical perspectives, empirical insights, and future directions. International Journal of English Studies, 10(2), 127.

[8] Bitchener, J., \& Knoch, U. (2009). The contribution of written corrective feedback to language development: A ten month investigation. Applied Linguistics, 31(2), 193-214.

[9] Blaxter, L., Hughes, C., \& Tight, M. (2010). How to research. ( $4^{\text {th }}$ ed.). England, Berkshire: Open University Press.

[10] Brown, H. D. (2000). Principles of language learning and teaching. ( $2^{\text {nd }}$ ed.). New York: Pearson Education.

[11] Cook, T. D. (2002). Randomized experiments in educational policy research: A critical examination of the reasons the educational evaluation community has offered for not doing them. Educational Evaluation and Policy Analysis 24(3), 175199

[12] Cook, V. J. (2008). Second language learning and language teaching. ( $4^{\text {th }}$ ed.). London: Hodder Education.

[13] Cook, V. J., \& Newson, M. (2007). Chomsky's universal grammar: An introduction. ( $3^{\text {rd }}$ ed.). Oxford: Blackwell Publishing.

[14] Crystal, D. (2013). The Cambridge encyclopedia of language. $\left(3^{\text {rd }}\right.$ ed.). Cambridge: Cambridge University Press.

[15] Crystal, D. (2008). A dictionary of linguistics and phonetics. $\left(6^{\text {th }}\right.$ ed.). Oxford: Blackwell Publishing.

[16] Deqi, Z. (2005). The process-oriented approach to ESL/EFL writing instruction and research. CELEA Journal, 28(5), 66-70.

[17] Denscombe, M. (2010). The good research guide: For smallscale social research projects. $\left(4^{\text {th }} \mathrm{ed}\right.$.). Maidenhead: McGrawHill Education.

[18] Dornyei, Z. (2007). Research methods in applied linguistics. Oxford: Oxford University Press.

[19] Ellis, R. (2008). The study of second language acquisition. ( $2^{\text {nd }}$ ed.). Oxford: Oxford University Press.

[20] Ellis, R. (1997). Second language acquisition. Oxford: Oxford University Press.

[21] Ellis, R. (1994). Understanding second language acquisition. Oxford: Oxford University Press.

[22] Ellis, R., Sheen, Y., Murakami, M., \& Takashima, H. (2008). The effects of focused and unfocused written corrective feedback in an English as a foreign language context. System, $36,353-371$.

[23] Elkillic, G., Han, T., \& Aydin, S. (2009). Punctuation and capitalisation errors of Turkish EFL students in composition classes: An evidence of L1 interference. In 1st International Symposium on Sustainable Development, Sarajevo, Bosnia and Herzegovina, 270-284.

[24] Erdogan, V. (2005). Contribution of error analysis to foreign language teaching. Mersin University Journal of the Faculty of Education, 1(2), 261-270.

[25] Erel, S., \& Bulut, D. (2007). Error treatment in L2 writing: A comparative study of direct and indirect coded feedback in Turkish EFL context. Erciyes University Journal of Social Sciences, 22, 397-415.

[26] Ferris, D. R. (2009). Teaching college writing to diverse student population. US, Ann Arbor: University of Michigan Press.

[27] Field, M. (2009). Improve your punctuation and grammar. (3 $3^{\text {rd }}$ ed.). New York: How To Books.

[28] Gomm, R., Hammersley, M., \& Foster, P. (2002). Case study method. Thousand Oaks, London: SAGE Publications.

[29] Halliday, M. (2003). On language and linguistics. New York: Continuum. 
[30] Hashimoto, M. (2004). An examination of ESL teachers' treatment of written errors (Doctoral thesis). Retrieved from $\mathrm{http} / / /$ epublications.bond.edu.au/theses/hashimoto/

[31] Hinkel, E. (2011). Handbook of research in second language teaching and learning. New York: Routledge.

[32] Iseni, A. (2011). Assessment, testing and correcting students' errors and mistakes. Language Teaching in Asia, 1(3), 60-90.

[33] Keshavarz, M. (2004). Contrastive analysis and error analysis. Tehran: Rahnama Publisher.

[34] Kavaliauskiene, G. (2009). Role of the mother tongue in learning English for specific purposes. ESP World, 1(8), 1-12

[35] Kumar, R. (2011). Research methodology: A step-by-step guide for beginners. ( ${ }^{\text {rd }}$ ed.). London: SAGE Publications.

[36] Lee, N. (1997). ESL learners' performance in error correction in writing: Some implication for teaching, System, 25(4), 465477.

[37] Lightbown, P. M., \& Spada, N. (2013). How languages are learned. ( $4^{\text {th }}$ ed.). Oxford: Oxford University Press.

[38] Lowhorn, G. L. (2007). Qualitative and quantitative research: How to choose the best design. In Academic Business World International Conference, Nashville, Tennessee. Retrieved from

http://papers.ssrn.com/sol3/papers.cfm?abstract_id=2235986

[39] Mackey, A., \& Gass, S. M. (2005). Second language research. London: Lawrence Erlbaum Associates Publishers.

[40] Mahan, K. R. (2013). Lexical errors in Norwegian intermediate and advanced learners of English (Master thesis, University of Oslo). Retrieved from https://www.duo.uio.no/handle/10852/37040

[41] McDonogh, S. (2002). Interlanguage studies, applied linguistics in language education. Oxford: Oxford University Press.

[42] McGowan, H. M. (2011). Planning a comparative experiment in educational settings. Journal of Statistics Education, 19(2), $1-19$

[43] Mitchell, R., Myles, F., \& Marsden, E. (2013). Second language learning theories. ( $3^{\text {rd }}$ ed.). London: Tylor and Francis.

[44] Myles, J. (2002). Second language writing and research: The writing process and error analysis in student texts. TESL-EJ, 2, 1-20.

[45] Naruemon, D. (2012). Causes of English spelling errors made by Thai foreign language learners. ARECLS, 10, 22-43.

[46] Nunan, D. (2001). Second language teaching and learning. US, Boston: Heinle \& Heinle Publishers.

[47] O'Leary, Z. (2010). The essential guide to doing your research project. London: SAGE Publications.
[48] Ortega, L. (2009). Understanding second language acquisition. London: Hodder Education.

[49] Payne, G., \& Payne, J. (2004). Key conceptions in social research. London: SAGE Publications.

[50] Peck, J., \& Coyle, M. (2005). The student's guide to writing: Grammar, punctuation and spelling. ( $2^{\text {nd }}$ ed.). London: Palgrave Macmillan.

[51] Punch, K. (2009). Introduction to research methods in education. London: SAGE Publications.

[52] Ridha, N. S. (2012). The effect of EFL learners' mother tongue on their writings in English: An error analysis study. Journal of the College of Arts, University of Basrah, 60, 22-45.

[53] Sadeghpour, M. (2013). An overview on the second language written error treatment. International Journal of Language Learning and Applied Linguistics World, 3(4), 192-200.

[54] Salusbury, M. (2004, June 25). Kurdistan at language crossroads. The Guardian. Retrieved from http://www.theguardian.com/education/2004/jun/25/tefl

[55] Shokouhi, H., \& Dabbagh, S. Z. (2009). Punctuation and spelling in learner's writing. Asian EFL Journal Press, 40, 3-27.

[56] Silverman, D. (2013). Doing qualitative research. (4 ${ }^{\text {th }}$ ed.). London: SAGE Publications.

[57] Simensen, A. M. (1998). Teaching a foreign language. Bergen: Fagbokforlaget Vigmostad \& Bjorke AS.

[58] Smith, R. (2005). Global English: Gift or curse? English Today, 21(2), 56-62.

[59] Soiferman, L. K. (2010). Compare and contrast inductive and deductive research approaches (University of Manitoba). Retrieved from http://files.eric.ed.gov/fulltext/ED542066.pdf

[60] Subhi, S. N., \& Yasin, M. S. M. (2015). Investigating study of an English spelling errors: A simple of Iraqi students in Malaysia. International Journal of Education and Research, 3, 235-246.

[61] Summer, M. (2006). Qualitative research. In V. Jupp (Ed.), the SAGE Dictionary of Social Research Methods (pp. 248 249). London: SAGE Publications.

[62] Tootkaboni, A. A., \& Khatib, M. (2014). The efficacy of various kinds of error feedback on improving writing accuracy of EFL learners. Bellaterra Journal of Teaching \& Leaning Language \& Literature, 7(3), 30-46.

[63] Tsai, Y. R., \& Lin, C. F. (2012). Investigating the effects of applying monitoring strategy in EFL writing instruction. International Journal of Business and Social Science, 3, 205216.

[64] Weir, C. (1988). Academic writing- can we please all the people all the time? In P. C. Robinson's 1988 (ed.). Academic Writing: Processes and Product. ELT Document 129, 17-34. 